\title{
SILICON TITANIUM OXIDE NANOPARTICLES CAN STIMULATE PLANT GROWTH AND THE PHOTOSYNTHETIC PIGMENTS ON LETTUCE CROP
}

\author{
NUNO MARIZ-PONTE ${ }^{1 *}$, SARA SARIO ${ }^{1}$, RAFAEL J. MENDES ${ }^{1}$, CRISTIANA V. CORREIA ${ }^{1}$, \\ JOSÉ MOUTINHO-PEREIRA², CARLOS M. CORREIA², CONCEIÇÃO SANTOS ${ }^{1}$
}

\author{
${ }^{1}$ University of Porto, Porto, Portugal \\ ${ }^{2}$ University of Trás-os-Montes e Alto Douro, Portugal
}

\begin{abstract}
MARIZ-PONTE, N. - SARIO, S. - MENDES, R.J - CORREIA, C.V. - MOUNTINHO-PEREIRA, J. - CORREIA, C.M. - SANTOS, C.: Silicon titanium oxide nanoparticles can stimulate plant growth and the photosynthetic pigments on lettuce crop. Agriculture (Pol'nohospodárstvo), vol. 66, no. 4, pp. 148-160.
\end{abstract}

\begin{abstract}
Our knowledge of the bioactivity of silicon titanium oxide nanoparticles $\left(\mathrm{TiSiO}_{4} \mathrm{NPs}\right)$ in crops is scarce, contrarily to $\mathrm{TiO}_{2} \mathrm{NPs}$ and $\mathrm{SiO}_{2} \mathrm{NPs}$ that are used in many industrial sectors, and have emerged in nanoagriculture (e.g., as pesticides or nanofertilisers). To evaluate the potential of using $\mathrm{TiSiO}_{4} \mathrm{NPs}$ in nanoagriculture, it is necessary to characterize their potential benefits on crops and the safety doses. Here, we report for the first time the bioactivity of $\mathrm{TiSiO}_{4} \mathrm{NPs}$ (up to $100 \mathrm{mg} / \mathrm{L}$ ) in the model crop lettuce (Lactuca sativa L.) exposed for three weeks (from seeds/seedlings to pre-harvesting phase). The doses applied did not compromise the germination rate, and highly stimulated plant fresh matter. $\mathrm{TiSiO}_{4} \mathrm{NPs}_{\text {had beneficial }}$ effects on photochemical processes by increasing chlorophyll levels. Effects on photosynthesis are less evident but $\mathrm{TiSiO}_{4}$ NPs $(100 \mathrm{mg} / \mathrm{L})$ stimulated the photosynthetic potential, increasing $\mathrm{F} / \mathrm{F}_{\mathrm{m}}$ and ETR when compared to the $50 \mathrm{mg} / \mathrm{L}$ conditions. $\mathrm{TiSiO}_{4} \mathrm{NPs}_{\mathrm{S}}$ did not influence the net photosynthetic rate and other Calvin-cycle variables. Soluble sugars and starch levels

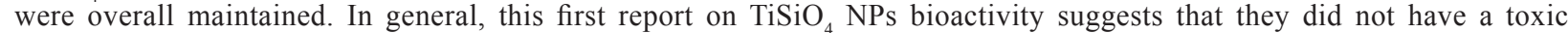
effect, and may be used to potentiate crops' growth. Principal component analysis (PCA) also shows that despite effects on photosynthetic performance is minimal regarding the control, the 50 and $100 \mathrm{mg} / \mathrm{L}$ doses strongly differ, with the lower dose promoting mostly pigment accumulation, while the higher dose slightly stimulates Photosystem II efficiency including the electron transport rate and other gas exchange parameters.
\end{abstract}

Key words: gas exchange, nanoagriculture, nanofertilisers, photosynthesis, $\mathrm{TiSiO}_{4}$

Nanotechnologies are increasingly providing new and promising manufactured nanomaterials, including nanoparticles, to the agricultural sector (Parisi et al. 2015). The first data regarding the use of titanium in plant production was obtained at the beginning of the last century and has become an important field in plant nutrition (Kováčik et al. 2014). Silicon titanium oxide $\left(\mathrm{TiSiO}_{4}\right)$ is a ternary system between titanium oxide $\left(\mathrm{TiO}_{2}\right)$ and silicon oxide $\left(\mathrm{SiO}_{2}\right)$ mixture that forms an orthorhombic structure, being increasingly used in multiple industries, particularly in the electronics sector (Garcia et al. 2009), ceramics (Varghese et al. 2011), optical instruments (Liu et al. 2017) and lubricant oils (Taheri et al. 2018). Despite their industrial potential, and unlike other metal nanoparticles, $\mathrm{TiSiO}_{4} \mathrm{NPs}$ remain

Nuno Mariz-Ponte (*Corresponding author), Sara Sario, Rafael J. Mendes, Cristiana V. Correia, Conceição Santos, LAQV-REQUIMTE, Department of Biology, Faculty of Sciences, University of Porto, Rua do Campo Alegre 4169-007, Porto, Portugal. E-mail: nuno.ponte@fc.up.pt

José Moutinho-Pereira, Carlos M. Correia, Department of Biology and Environment, Centre for the Research and Technology of Agro-Environmental and Biological Sciences (CITAB), University of Trás-os-Montes e Alto Douro, 5001-801 Vila Real, Portugal

(C) 2020 Authors. This is an open access article licensed under the Creative Commons Attribution-NonComercial-NoDerivs License (http://creativecommons.org/licenses/by-nc-nd/4.0/). 
unexplored in the nano-agroindustrial sector. Their antimicrobial activity was shown on Vibrio fischeri and Salmonella typhimurium (Pereira et al. 2011; Rodríguez-González et al. 2019). Also, using different concentrations up to $1,000 \mathrm{mg} / \mathrm{kg}$ soil or $1,000 \mathrm{mg} / \mathrm{L}$ (of aqueous suspensions), other authors as Bouguerra et al. (2016) observed that E. andrei only avoided the soils spiked with $1,000 \mathrm{mg} / \mathrm{kg} \mathrm{TiSiO}_{4}$ NPs. Despite still unknown, $\mathrm{TiSiO}_{4} \mathrm{NPs}_{\text {may be safe }}$ at low doses to plants as no negative effects were found on corn and oat seedlings growth, and only small decreases of dry mass and fresh mass were observed on lettuce and tomato seedlings (Bouguerra et al. 2016). Some authors suggested that AgNPs induce more severe effects on the behavior of the terrestrial organisms than $\mathrm{TiSiO}_{4} \mathrm{NPs}$, supporting the safe nature of these NPs. The lettuce market is huge being one of the most important leafy vegetable worldwide (Shatilov et al. 2019). Thus, is important to find strategies to improve the production of this crop.

On other hand, $\mathrm{TiSiO}_{4} \mathrm{NPs}$ are photocatalyst particles, and some NPs also with this characteristic, such as $\mathrm{TiO}_{2}$, have been demonstrated at moderate doses to increase the photosynthetic performance, plant productivity, and quality (Shabbir et al. 2019; Gohari et al. 2020; Tighe-Neira et al. 2020). Also, their antimicrobial activity opens perspectives for crop protection as suggested by Rodríguez-González et al. (2019). Between the titanium oxide $\mathrm{NPs}\left(\mathrm{TiO}_{2}\right.$ and $\mathrm{TiSiO}_{4}$ ), $\mathrm{TiO}_{2} \mathrm{NPs}$ are vastly more studied in terms of plant response, using physiological and biochemical approaches (El-Ramady et al. 2018; Ghosh et al. 2019; Silva et al. 2016; 2017a,b, 2019, Dias et al. 2019). Among the NPs with agricultural potential, those of $\mathrm{TiO}_{2}$ are increasingly being used (Siddiqui et al. 2015; Duhan et al. 2017). The potential usefulness of $\mathrm{TiO}_{2} \mathrm{NPs}$ in nanoagriculture may rely on their multiple functionalities, which include: a) antimicrobial activity (critical during germination and seedlings' first days) with the potential to manage plant diseases (Soni \& Prakash 2012; Sekhon 2014; Duhan et al. 2017); b) stimulation of plant growth under certain doses (Jaberzadeh et al. 2013; Siddiqui et al. 2015). Likewise, $\mathrm{SiO}_{2}$ (another component of the ternary system of $\mathrm{TiSiO}_{4}$ NPs) has been reported to promote biofortification in plants, to be responsible for promoting the strengthening of the cell walls (Guerreiro et al. 2016), has a mitigation role under abiotic stress (Behboudi et al. 2018), and is also increasingly being used on agricultural applications (Jampílek \& Král'ová 2017; Luyckx et al. 2017).

As $\mathrm{TiSiO}_{4}$ NPs impacts on plants remain unknown, we hypothesise that these NPs may combine the positive effects of the $\mathrm{TiO}_{2}$ and $\mathrm{SiO}_{2} \mathrm{NPs}$. Under moderate doses, $\mathrm{TiO}_{2} \mathrm{NPs}$ were reported to stimulate plant biomass and positively regulate $\mathrm{N}$ metabolism (Yang et al. 2006). Recent data also pinpointed that $\mathrm{TiO}_{2} \mathrm{NPs}$ were able to modulate plants' response to other stressors, lowering the $\mathrm{Cu}(\mathrm{II})$ and Cd phytotoxicity in rice (Wang et al. 2015; Ji et al. 2017) and increasing wheat tolerance to water deficit (Jaberzadeh et al. 2013). Germination may not be affected or even be stimulated by $\mathrm{TiO}_{2} \mathrm{NPs}$ up to $750 \mathrm{mg} / \mathrm{kg}$ (Yang et al. 2015; Andersen et al. 2016; Maity et al. (2018). $\mathrm{SiO}_{2}$ NPs have been presented as a stimulator of yield and plant performance under unfavourable environment conditions, such as drought in the cotton plants (Behboudi et al. 2018).

Positive impacts in photosynthesis have been reported to $\mathrm{TiO}_{2} \mathrm{NPs}$ and $\mathrm{SiO}_{2} \mathrm{NPs}$ such as promoting electron transfer (Lei et al. 2007), increased transpiration rate (E), an increase of the net photosynthetic rate $(\mathrm{Pn})$, stomatal conductance (gs) (Ashkavand et al. 2018). However, it should be noted that most studies on $\mathrm{TiO}_{2} \mathrm{NPs}$ and $\mathrm{SiO}_{2} \mathrm{NPs}$ bioactivity/phytotoxicity are performed during short periods. Studies using chronical exposure, whilst scarce, are much closer to real scenarios (Karunakaran et al. 2017; Silva et al. 2017a). Additionally, besides the species model, factors such as NPs size, shape, the presence and type of surface-coating, and NPs concentration vary greatly among studies, it can result in conflicting reports of their bioactivity (Cox et al. 2016; Silva et al. 2016; 2017b). Finally, phytotoxicity of high doses, particularly of the $\mathrm{TiO}_{2} \mathrm{NPs}$, is being unveiled by our and other groups, with description for example of the reduction of root growth, among other effects (Andersen et al. 2016; Cox et al. 2016; Karunakaran et al. 2017; Silva et al. 2016, 2017a,b, 2019).

Considering the complex data of the other NPs, it is critical to increase the available information on

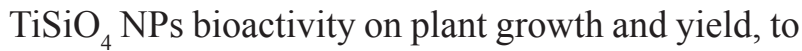
elucidate their potential for nanoagriculture. This in- 
formation is crucial to evaluate if and how these NPs interact with crops' performance, their entrance into the food chain, and if they can replace/complement $\mathrm{TiO}_{2} \mathrm{NPs}, \mathrm{SiO}_{2} \mathrm{NPs}$, or both in nanoagroindustry.

Here, we hypothesise that $\mathrm{TiSiO}_{4}$ NPs may retain some beneficial properties and effects of the $\mathrm{TiO}_{2} \mathrm{NPs}$ and $\mathrm{SiO}_{2} \mathrm{NPs}$ on crops, and thus may combine little or none toxicity with stimulation of growth and crop's performance, namely at the photosynthetic level. To test this hypothesis, lettuce plants (a major dicotyledonous model crop) were exposed to two different doses of $\mathrm{TiSiO}_{4} \mathrm{NPs}$ for three weeks, after which several photosynthesis-related endpoints (leaf gas exchange, chlorophyll $a$ fluorescence, ribulose-1,5-bisphosphate carboxylase/oxygenase - RuBisCO amount, pigments and carbohydrates contents) were quantified.

\section{MATERIAL AND METHODS}

Nanoparticles stocks, characterization, and preparation of solutions

$\mathrm{TiSiO}_{4} \mathrm{NPs}(>99.8 \%$ purity) were purchased from Sigma-Aldrich (St. Louis, MO-USA) having, according to the supplier, a primary size $<50 \mathrm{~nm}$. $\mathrm{TiSiO}_{4} \mathrm{NPs}$ dynamic light scattering (DLS) and zeta potential were characterized according to our current techniques (Bastos et al. 2017). A stock suspension of $1.0 \mathrm{~g} / \mathrm{L} \mathrm{TiSiO}{ }_{4}$ NPs (in distilled water) was used for the preparation of final nutrient solutions (Hoagland basal salt mixture, Sigma-Aldrich, USA) with concentrations up to $100 \mathrm{mg} / \mathrm{L}$. All suspensions were sonicated for $\approx 20 \mathrm{~min}$ prior to use.

\section{Seed germination and exposure to $\mathrm{TiSiO}_{4} \mathrm{NPS}$}

Seeds of L. sativa cv. 'Maravilha de Verão Canasta' (Vilmorin Jadin, France) were germinated in Petri dishes (100 seeds/petri dish), each with $10 \mathrm{~mL}$ of nutrient solution with different $\mathrm{TiSiO}_{4} \mathrm{NPs}$ concentrations: 0,50 , and $100 \mathrm{mg} / \mathrm{L}$. Germination took place at $16 \mathrm{~h}$ light period (Photosynthetically active radiation - PAR $\left.\approx 100 \mu \mathrm{mol} / \mathrm{m}^{2} / \mathrm{s}\right), 20 \pm 2^{\circ} \mathrm{C}, \approx 50 \%$ relative humidity $(\% \mathrm{RH})$. One-week-old seedlings were hydroponically grown on the corresponding media at PAR $\approx 200 \mu \mathrm{mol} / \mathrm{m}^{2} / \mathrm{s}, 16 \mathrm{~h}$ light periods, $22 \pm 2^{\circ} \mathrm{C}, \approx 45 \% \mathrm{RH}$. All media were renewed every 3 days, and $\mathrm{pH}$ was kept constant at $\approx 5$.6. After 3 weeks, plant growth and biomass were determined by assessing shoot and root length, and fresh (FM) and dry (DM) matters. Morphological data were registered (senescence, chlorosis, necrotic spots, and abscission).

\section{Photosynthetic analyses}

L. sativa leaves in the rosette stage (first rosette leaves) grown at 0,50 , and $100 \mathrm{mg} / \mathrm{L}$ were used in photosynthetic assays. For pigments determination, leaves were homogenized in acetone: $50 \mathrm{mM}$ Tris buffer $(80: 20)(\mathrm{pH} \approx 7.8)$ (Sims \& Gamon 2002). Chlorophyll $a(\mathrm{Chl} a)$, chlorophyll $b(\mathrm{Chl} b)$, carotenoids, and anthocyanins were quantified at 470 , 537, 647, and $663 \mathrm{~nm}$.

The basal fluorescence yield of dark-adapted samples $\left(\mathrm{F}_{0}\right)$, the maximal fluorescence yield $\left(\mathrm{F}_{\mathrm{m}}\right)$, and the variable fluorescence $\left(\mathrm{F}_{\mathrm{v}}=\mathrm{F}_{\mathrm{m}}-\mathrm{F}_{0}\right)$ were measured with the respective light conditions. The parameters $\mathrm{F}_{0}, \mathrm{~F}_{\mathrm{m}}$, and $\mathrm{F}_{\mathrm{v}}$, were also assessed in 30 min illuminated leaves. $\mathrm{F}_{\mathrm{v}} / \mathrm{F}_{\mathrm{m}}$ and $\mathrm{F}_{\mathrm{v}}{ }^{\prime} / \mathrm{F}_{\mathrm{m}}{ }^{\prime}$, and the effective photochemical efficiency of PSII $\left(\Phi_{\text {PSII }}\right)$, photochemical quenching $\left(\mathrm{q}_{\mathrm{p}}\right)$, and electron transport rate (ETR) were determined (Maxwell \& Johnson 2000).

For leaf gas exchange analysis, the infra-red gas analyser (LCpro+, ADC, Hoddesdon, UK), operating in open mode, was used. Measurements took place under atmospheric $\mathrm{CO}_{2}$ concentration with a saturating photosynthetic photon flux density of $600 \mu \mathrm{mol} \mathrm{m} / \mathrm{s}$. Transpiration rate $\left(E, \mathrm{mmol}\left(\mathrm{H}_{2} \mathrm{O}\right)\right.$ $\left.\mathrm{m}^{2} / \mathrm{s}\right)$, stomatal conductance $\left(g_{\mathrm{s}}, \mathrm{mmol}\left(\mathrm{H}_{2} \mathrm{O}\right) \mathrm{m}^{2} / \mathrm{s}\right)$, net photosynthetic rate $\left(\mathrm{Pn}, \mu \mathrm{mol}\left(\mathrm{CO}_{2}\right) \mathrm{m}^{2} / \mathrm{s}\right)$ and the ratio of intercellular $\mathrm{CO}_{2}$ concentration to ambient $\mathrm{CO}_{2}\left(C_{i} / C_{a}\right)$ were determined (Rodriguez et al. 2015).

\section{Carbohydrates quantification}

Total soluble sugars (TSS) and starch contents ( $\mathrm{mg} / \mathrm{g} \mathrm{FM}$ ) were quantified by the anthrone method (Osaki et al. 1991; Irigoyen et al. 1992).

\section{RuBisCO quantification}

Soluble proteins extracted from the first rosette leaves were quantified by the Bradford method (Sigma-Aldrich, USA). For RuBisCO analysis, $15 \mu \mathrm{g}$ of protein were separated by SDS-PAGE, using protein molecular weight marker (Fermentas SM0441, ThermoFisher, USA) as a reference, and bands were 
stained with $0.25 \%$ Coomassie Brilliant Blue R250 (Li et al. 2013). Relative RuBisCO quantification of large and small subunits was done after overnight incubation in $2 \mathrm{~mL}$ formamide at $50^{\circ} \mathrm{C}$, reading absorbance at $595 \mathrm{~nm}$. Results are expressed as ABS $/ \mathrm{ABS}_{\text {Protein content. }}$

\section{Statistical analysis}

Experiments used 6-8 plant samples (treated individually or as leaf pools), and 3 independent technical replicates. Comparisons between the different conditions were made using the One-Way ANOVA test, using GraphPad Prism 6 (GraphPad Software, San Diego, California, USA). For different conditions, the Tukey Comparison Test $(p<0.05)$ was used. Multivariate analyses for data correlation used Principal component analysis (PCA) and were performed with CANOCO 5 (WUR, Netherland).

\section{RESULTS}

Nanoparticles characterization and effect on germination and plant growth

Taking into account the size of $\mathrm{TiSiO}_{4} \mathrm{NPs}(<50$ $\mathrm{nm}$ in aqueous suspensions), these NPs tend to form aggregates confirming previous data, and according to the DLS data, their hydrodynamic diameter was 2 to 3 times larger than the primary particle size, reaching average sizes of $115 \pm 29 \mathrm{~nm}$.

Seeds in all concentrations reached a germination rate of $\geq 99 \%$, supporting no negative effects of these NPs on this crop's germination. Whilst root length and fresh matter (FM) of exposed plants were not affected compared to unexposed roots, both shoot length and, mainly shoots' FM, were in general stimulated by $\mathrm{TiSiO}_{4}$ NPs compared to control plants (Table 1).

\section{Photosynthetic pigments content and fluorescence}

The average values of Chl $a$ and $b$ contents were stimulated by $\mathrm{TiSiO}_{4}$ NPs (Figure 1a, b) with maximum values being achieved at $50 \mathrm{mg} / \mathrm{L}(p<0.05)$. The ratio Chl $a / \mathrm{Chl} b$ was increased $(p<0.05)$ by

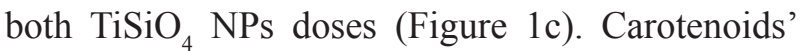
levels were not changed by $\mathrm{TiSiO}_{4} \mathrm{NPs}$ (Figure 1d). Finally, the anthocyanin levels were significantly increased at $50 \mathrm{mg} / \mathrm{L} \mathrm{TiSiO}_{4} \mathrm{NPs}$ (Figure 1e).

Basal chlorophyll fluorescence of dark-adapted leaves $\left(\mathrm{F}_{0}\right)$ was slightly decreased $(p<0.05)$ by

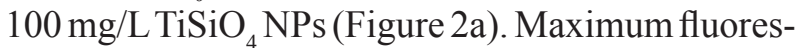
cence $\left(\mathrm{F}_{\mathrm{m}}\right)$ and variable fluorescence (Figure $2 \mathrm{~b}, \mathrm{c}$ )
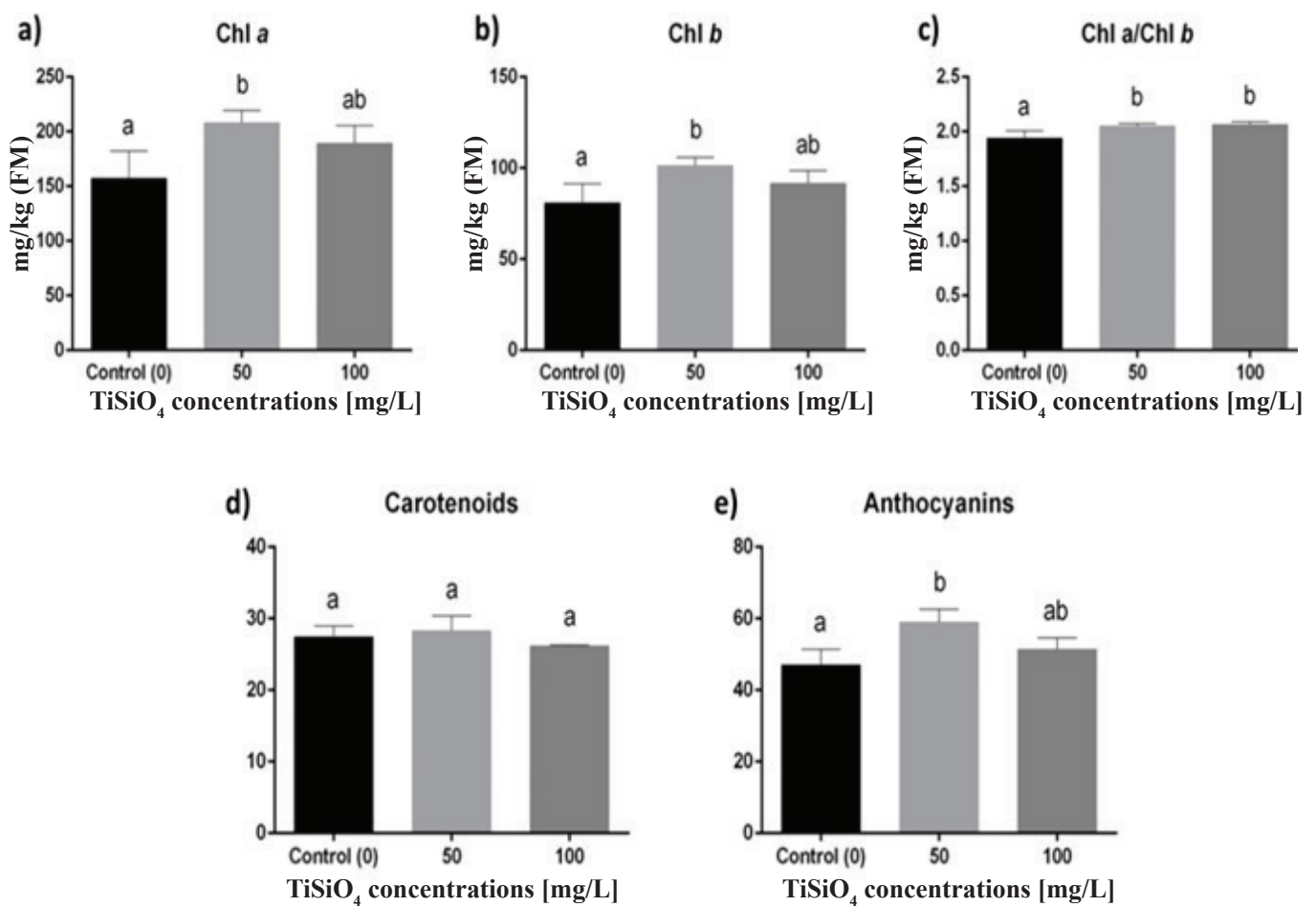

Figure 1. Pigment contents (mg/kg (FM)) in plants exposed to $\mathrm{TiSiO}_{4} \mathrm{NPs}_{4}$.

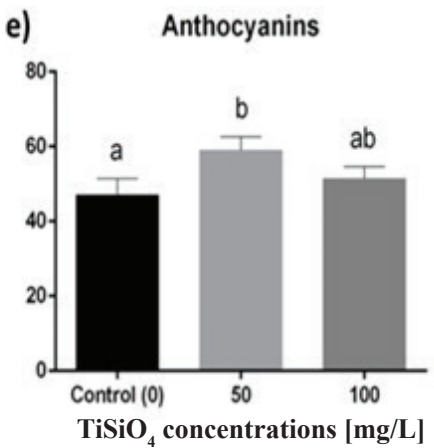

a) chlorophyll $a$; b) chlorophyll $b$; c) ratio Chl $a / \mathrm{Chl} b$; d) Carotenoids; e) Anthocyanins; FM - Fresh Matter.

All conditions were compared by Tukey multi comparison test using one-way ANOVA for $p<0.05$. 
were not compromised $(p>0.05)$ in exposed plants, $100 \mathrm{mg} / \mathrm{L}$ compared to $50 \mathrm{mg} / \mathrm{L}$ (Figure $2 \mathrm{f}$ ). For the but the increase of $\mathrm{F}_{\mathrm{v}} / \mathrm{F}_{\mathrm{m}}$ ratio at $100 \mathrm{mg} / \mathrm{L}$ was sig- photosystem efficiency, $\Phi_{\text {PSII }}$ was affected by $\mathrm{TiSiO}_{4}$ nificant compared to $50 \mathrm{mg} / \mathrm{L}$ condition ( $p<0.05$; NPs doses also with increases at $100 \mathrm{mg} / \mathrm{L} \mathrm{com-}$ Figure 2d). Regarding the light-adapted state, $\mathrm{F}_{\mathrm{v}}{ }^{\prime} \mathrm{F}_{\mathrm{m}}{ }_{\mathrm{m}}$ pared to $50 \mathrm{mg} / \mathrm{L}$ (Figure 2e). The $\mathrm{q}_{\mathrm{p}}$ parameter was ratio was affected increasing substantially at not affected by any NPs dose (Figure 2g). Lastly,

$\mathrm{T}$ a

Growth parameters of lettuce roots and shoots exposed to $\mathrm{TiSiO}_{4} \mathrm{NPs}$

\begin{tabular}{|c|c|c|c|}
\hline Plant area evaluated & Control & $50 \mathrm{mg} / \mathrm{L}$ & $100 \mathrm{mg} / \mathrm{L}$ \\
\hline Root Length [cm] & $12.83 \pm 2.15$ & $11.170 \pm 1.56$ & $12.46 \pm 1.95$ \\
\hline Shoot Length $[\mathrm{cm}]$ & $9.94 \pm 2.18$ & $12.826 \pm 2.30$ & $10.44 \pm 2.42$ \\
\hline Root Fresh Matter [g] & $8.49 \pm 2.43$ & $10.680 \pm 3.52$ & $10.62 \pm 2.10$ \\
\hline Shoot Fresh Matter [g] & $11.22 \pm 1.57$ & $14.030 \pm 1.33^{*}$ & $19.53 \pm 2.54 *$ \\
\hline
\end{tabular}

For the same condition and organ *means significantly different values $(p<0.05)$ in comparison with the control.
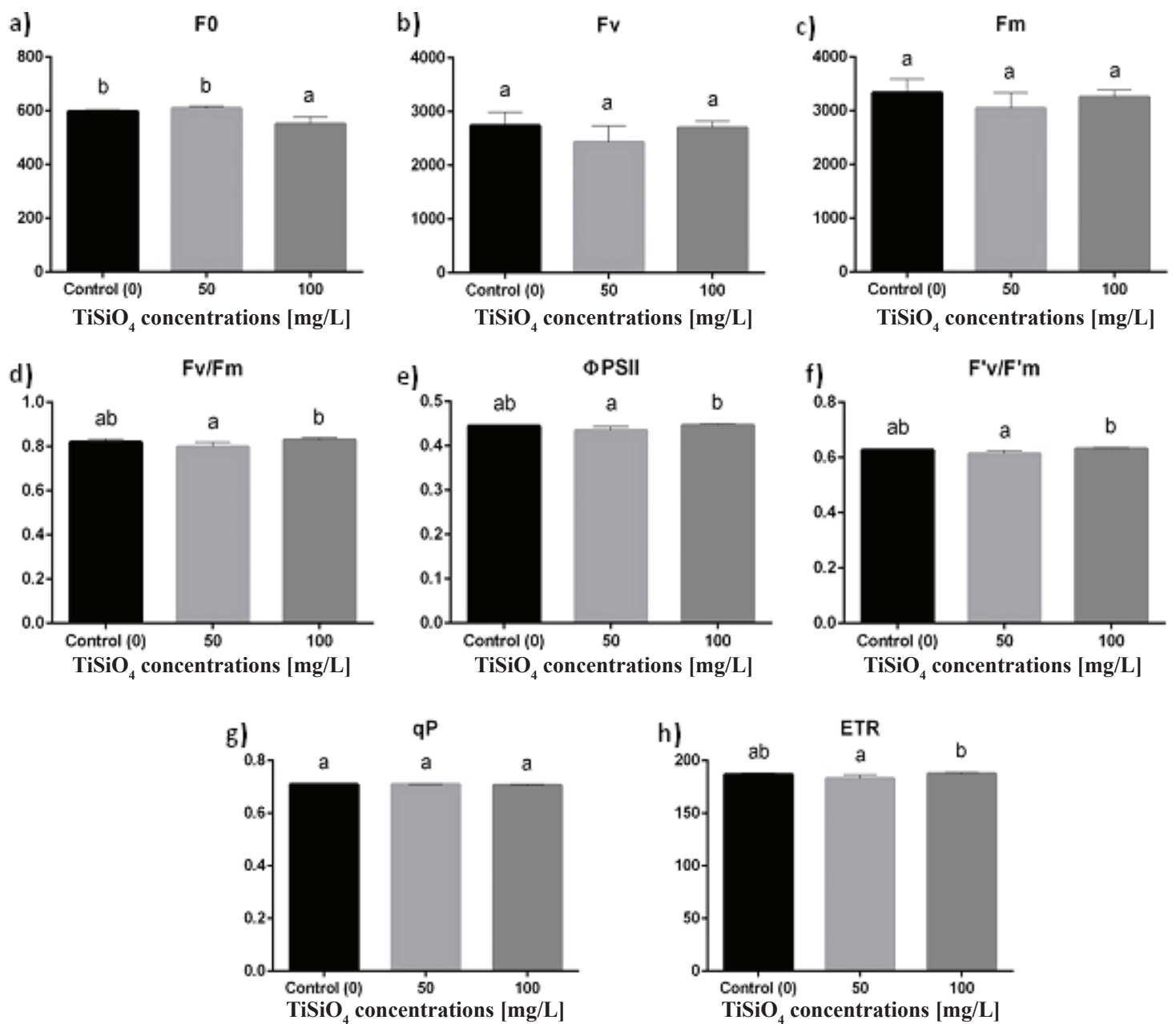

Figure 2. Fluorescence data (AU - arbitrary units) of plants exposed to $\mathrm{TiSiO}_{4} \mathrm{NPs}$. a) $\mathrm{F}_{0}$ - minimal fluorescence of darkadapted leaves; b) $\mathrm{F}_{\mathrm{v}}$ - variable fluorescence of dark-adapted leaves; c) $\mathrm{F}_{\mathrm{m}}$ - maximum fluorescence of dark-adapted leaves; d) $\mathrm{F}_{\mathrm{v}} / \mathrm{F}_{\mathrm{m}}$ - maximum quantum yield; e) $\Phi_{\mathrm{PSII}}$ - effective quantum yield; $\mathrm{f}$ ) $\mathrm{F}_{\mathrm{v}}, \mathrm{F}_{\mathrm{m}}$ ' - maximum quantum yield in light-adapted condition; g) $\mathrm{q}_{\mathrm{p}}$ - photochemical quenching; h) ETR - electron transport rate.

All conditions were compared by Tukey multi comparison test using one-way ANOVA for $p<0.05$. 
ETR was stimulated $(p<0.05)$ by $100 \mathrm{mg} / \mathrm{L}$ dose compared to $50 \mathrm{mg} / \mathrm{L}$ (Figure $2 \mathrm{~h}$ ).

Gas exchange, RuBisCO, and carbohydrate levels

Leaf gas exchange parameters showed that the use of $\mathrm{TiSiO}_{4} \mathrm{NPs}$ did not affect the potential use of $\mathrm{CO}_{2}$ by L. sativa plants. Significant differences between each condition for all parameters (Figure 3a-e) were not found. Also, the parameters related to carbon assimilation, such as RuBisCO, TSS, and starch contents were not significantly affected by the $\mathrm{TiSiO}_{4}$ NPs doses used (Figure 4a-c). a)

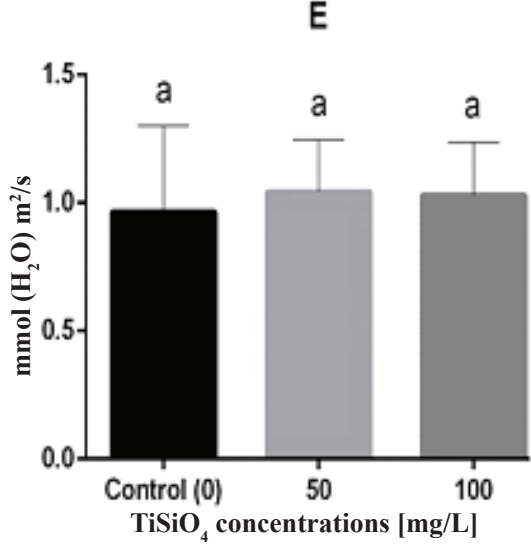

d) b)

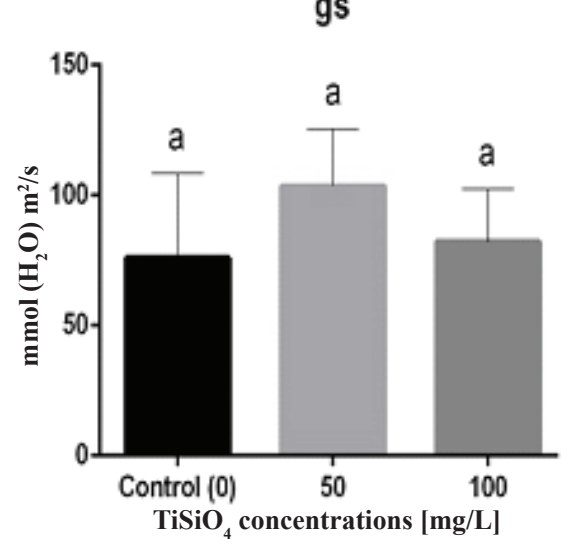

c)

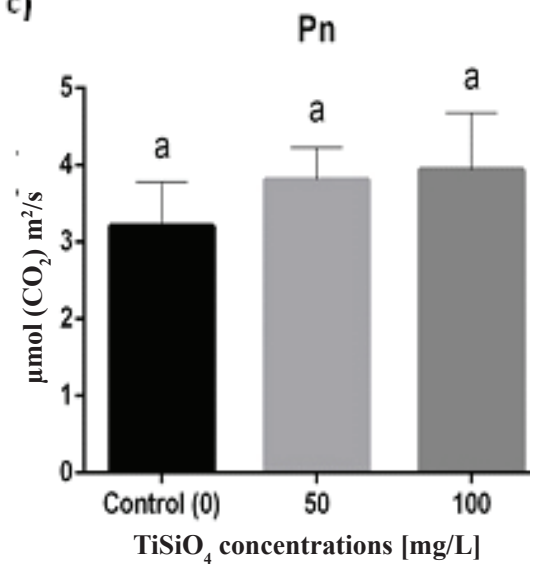

$\mathrm{Pn} / \mathrm{gs}$

e)
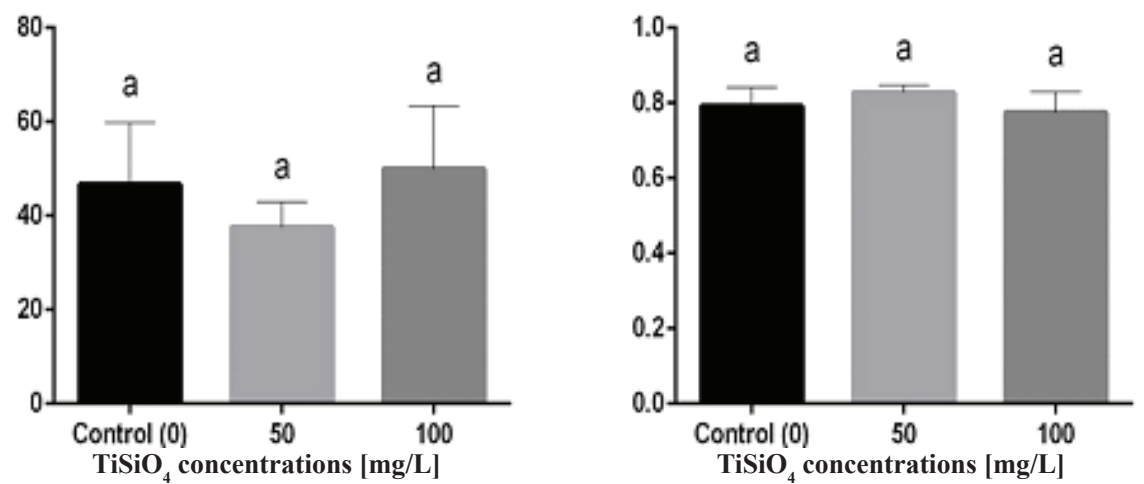

Figure 3. Leaf gas-exchange in plants exposed to $\mathrm{TiSiO}_{4} \mathrm{NPs}$. a) $\mathrm{E}\left(\mathrm{mmol}\left(\mathrm{H}_{2} \mathrm{O}\right) \mathrm{m}^{2} / \mathrm{s}\right)$ - transpiration rate; b) gs - stomatal conductance; c) Pn $\left(\mu \mathrm{mol}\left(\mathrm{CO}_{2}\right) \mathrm{m}^{2} / \mathrm{s}\right)$ - net photosynthetic rate; d) $\mathrm{Pn} / \mathrm{gs}$ ratio $-\mathrm{Pn} / \mathrm{gs}-\mathrm{CO}_{2}$ assimilation efficiency; e) $\mathrm{C}_{\mathrm{i}} / \mathrm{C}_{\mathrm{a}}$ - intercellular $\mathrm{CO}_{2}$ ratio.

All conditions were compared by Tukey multi comparison test using one-way ANOVA for $p<0.05$.

A)

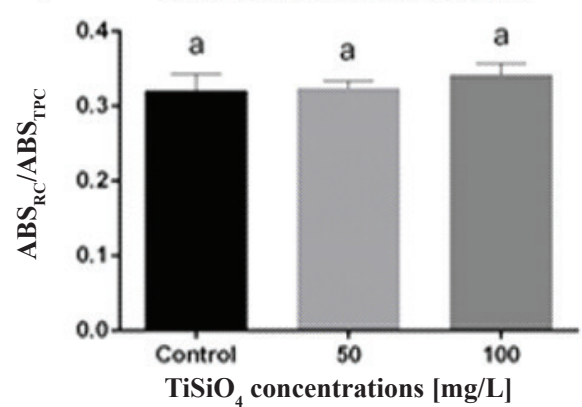

B)

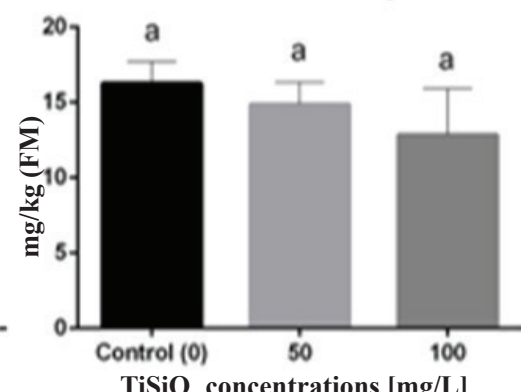

C)

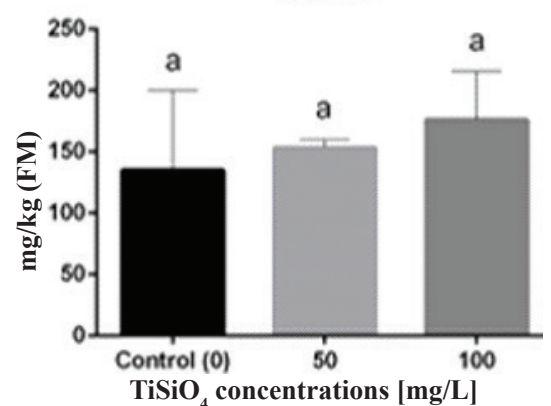

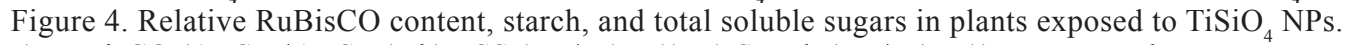

a) RuBisCO ( $\mathrm{ABS}_{\mathrm{RC}} / \mathrm{ABS}_{\mathrm{TPC}}$ ); b) TSS (mg/g (FM)); c) Starch (mg/g (FM)); FM - Fresh Matter.

All conditions were compared by Tukey multi comparison test using one-way ANOVA for $\mathrm{p}<0.05$. 


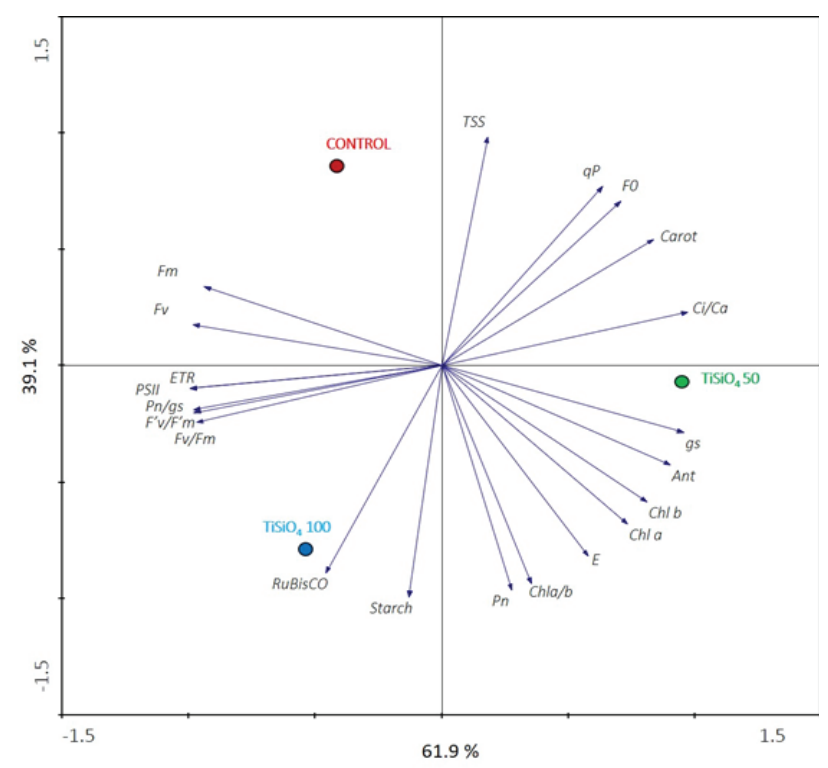

Figure 5. Principal component analysis (PCA) of functional responses of plants exposed to $\mathrm{TiSiO}_{4} \mathrm{NPs}$

PCA (Figure 5) shows a distinct separation between all conditions used in physiological studies $(0,50$, and $100 \mathrm{mg} / \mathrm{L})$. PC1 (F1) explains $61.9 \%$ of the variance, while PC2 (F2) explains 39.1\%. The control population is located on the down-right quadrant, and this parameter is the only located in the down-side of the Y-axis, associated with TSS and some fluorescence parameters $\left(\mathrm{F}_{\mathrm{v}}\right.$ and $\left.\mathrm{F}_{\mathrm{m}}\right)$. On the other hand, $50 \mathrm{mg} / \mathrm{L}$ is in the top-left quadrant and has positive scores for all photosynthetic pigments and $g_{s}$ parameter. Regarding yield parameters of photosynthesis, such as $\Phi_{\mathrm{PSII}}, \mathrm{F}_{\mathrm{v}} / \mathrm{F}_{\mathrm{m}}, \mathrm{F}_{\mathrm{v}}{ }_{\mathrm{v}} / \mathrm{F}_{\mathrm{m}}$, ETR, Pn $/ \mathrm{g}_{\mathrm{s}}, \mathrm{RuBisCO}$, and starch contents, these are clusters on the top-right quadrant, corresponding to the $100 \mathrm{mg} / \mathrm{L}$ samples.

\section{DISCUSSION}

$\mathrm{TiO}_{2}$ and $\mathrm{SiO}_{2}$ NPs bioactivity in plants are currently under debate to support their potential use in nanoagriculture (Srivastava et al. 2015). Whilst most studies are focused on $\mathrm{TiO}_{2}$ showing antibiotic activity and at some limited doses a stimulation of growth (but also toxicity at higher doses), $\mathrm{SiO}_{2}$ is mostly pinpointed as a potential source of release of $\mathrm{Si}$ with demonstrated benefits to plant growth, and thus with potential as a nano fertiliser. The combination of $\mathrm{Ti}$ and $\mathrm{Si}$ may thus combine some of the beneficial effects with minimal toxicity. However, the characterization of the $\mathrm{TiSiO}_{4}$ NPs bioactivity in plants remains scarcely addressed. Moreover, most of the studies performed up to the moment with NPs used short term exposures, while agricultural purposes demand long term-exposure studies.

Ti is well known to be an element that when found in soils and waters used for plant growth, it enhances not only the plants' photosynthesis, but also their chlorophyll content, which promotes nutrient uptake, better stress tolerance, and improves crop yield and quality, making this a beneficial element (Lyu et al. 2017). On the other hand, the beneficial effects of silicon to plants are widely demonstrated (Murad et al. 2020) and its oxidised form ( $\mathrm{SiO}_{2} \mathrm{NPs}$ ) promoted plant protection against biotic and abiotic stress (Luyckx et al. 2017). Our work contains the first results addressing $\mathrm{TiSiO}_{4}$ NPs photosynthetic bioactivity in plants, and we demonstrate that, after short-term exposure, moderate doses of $\mathrm{TiSiO}_{4} \mathrm{NPs}$ might stimulate lettuce growth, and may positively influence, in yet to unveil mechanisms, photosynthetic parameters, such as the increase of photosynthetic pigments at lower doses $(50 \mathrm{mg} / \mathrm{L})$ and gas exchange and PSII efficiency at higher doses (100 $\mathrm{mg} / \mathrm{L})$.

Recently we have demonstrated for Triticum aestivum that chronical exposure to $\mathrm{TiO}_{2} \mathrm{NPs}$ influences photosynthesis, and for example, $150 \mathrm{mg} / \mathrm{L} \mathrm{TiO}_{2} \mathrm{NPs}$ had phytotoxic effects (stimulating oxidative stress and water disorders), which impaired plant growth, being toxicity more severe in shoots than in roots (Silva et al. 2017a; 2019). Using fresh and dry matter as growth indicators, and soils contaminated with extremely high doses $\left(1,000 \mathrm{mg} / \mathrm{kg}\right.$ soil $\left._{\mathrm{DM}}\right)$, Bouguerra et al. (2016) reported $\mathrm{TiSiO}_{4} \mathrm{NPs}$ phytotoxicity in lettuce and tomato plants. Comparing the available literature for $\mathrm{TiO}_{2} \mathrm{NPs}$ with our current data for $\mathrm{TiSiO}_{4} \mathrm{NPs}$, there is evidence of lower toxicity of $\mathrm{TiSiO}_{4} \mathrm{NPs}$, but further comparative studies under similar conditions must be conducted.

We demonstrate here that the interference of

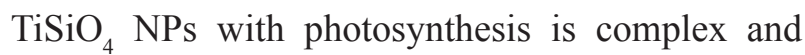
related to the dose, but overall a neutral or slight stimulation is found. Photophosphorylation is the source of ATP and NADPH $+\mathrm{H}^{+}$for the Calvin cycle to proceed, and its status here was evaluated according to changes in the chlorophyll quantity/ratio 
for $50 \mathrm{mg} / \mathrm{L} \mathrm{TiSiO}_{4} \mathrm{NPs}$ compared to control plants. It was evident that $50 \mathrm{mg} / \mathrm{L} \mathrm{TiSiO}_{4} \mathrm{NPs}_{\text {stimulated }}$ chlorophylls and anthocyanins contents (by increasing synthesis or preventing damage) which, besides photosynthesis, also have protective roles. The observed increase of $\mathrm{Chl}$ levels has been described in response to $\mathrm{TiO}_{2} \mathrm{NPs}$, often paralleled with an increase of $\mathrm{N}$ uptake, but the targets of these NPs in the plant metabolism remain unknown (Lyu et al. 2017). Kheyrkhah et al. (2018) showed that $\mathrm{SiO}_{2}$ and $\mathrm{TiO}_{2}$ increased the chlorophylls and carotenoids content in oilseed rape cultivars. Also, Aliabadi et al. (2015) showed that $100 \mathrm{mg} / \mathrm{L} \mathrm{TiO}_{2} \mathrm{NPs}$ increased the $\mathrm{Chl} a$ content and the ratio $(\mathrm{Chl} a / \mathrm{Chl} b)$ in T. aestivum. However, the same study also showed that using 20 times more concentration $(2,000$ $\mathrm{mg} / \mathrm{L}$ ) reduced $\mathrm{Chl}$ content and its ratio. This study, in parallel with our data, demonstrates that moderate doses are capable to increase the photosynthetic potential, however, the species factor should be considered. These rises may increase the efficiency of $\mathrm{CO}_{2}$ assimilation (Yang et al. 2006; Sanshez-Zabala et al. 2015; Lyu et al. 2017). Ti oxides NPs may also exert a protective role of photostability of chlorophylls, similarly to what was reported for silver nanoparticles (AgNPs) that slowed down the photodegradation of Chl $a$ (Barazzouk et al. 2012). Thus, the increase of chlorophylls by $\mathrm{TiSiO}_{4} \mathrm{NPs}$ suggests either increased synthesis or an improved photostability of the pigments. This increase of pigments will improve the capacity for harvesting photons to foster the photophosphorylation process. The protective role of these pigments against photooxidation should also not be excluded. On the other hand, the absence of changes in fluorescence parameters and gas exchange compared to control were a positive indicator that the doses tested are not a toxic concentration of this compound for L. sativa growing in hydroponic systems, using the photosynthesis and carbon metabolism as control endpoints. Nevertheless, the use of $\mathrm{TiO}_{2} \mathrm{NPs}$ in another crop, such as Solanum lycopersicum, was capable to promote an increase in photosynthetic parameters (Qi et al. 2013). Besides, our data showed a particularity on the $100 \mathrm{mg} / \mathrm{L}$ conditions, as increases occurred in some photosynthetic parameters $\left(\mathrm{F}_{\mathrm{v}} / \mathrm{F}_{\mathrm{m}}, \Phi_{\mathrm{PSII}}, \mathrm{F}_{\mathrm{v}}{ }_{\mathrm{v}} / \mathrm{F}_{\mathrm{m}}{ }_{\mathrm{m}}\right.$, and ETR) compared to $50 \mathrm{mg} / \mathrm{L}$. These results suggest that an increase of $\mathrm{TiSiO}_{4}$ NPs relative to
$50 \mathrm{mg} / \mathrm{L}$ can promote a positive effect in photosynthesis performance and the $100 \mathrm{mg} / \mathrm{L}$ concentration may not be the maximum endpoint of high photosynthetic performance for $L$. sativa.

Interestingly, the PCA analyses confirm a hormesis response in some parameters, shown by a negative correlation between $50 \mathrm{mg} / \mathrm{L}$ and the dark-adapted parameters of $F_{m}, F_{v}, F_{v} / F_{m}$, and $F_{v}{ }_{v} / F_{m}$, while 100 $\mathrm{mg} / \mathrm{L}$ had a similar negative correlation with $\mathrm{F}_{0}$. A higher $\mathrm{F}_{0}$ can be interpreted as indicating irreversible damage to PSII (Bussotti et al. 2011), therefore the decrease of $\mathrm{F}_{0}$ in exposed leaves may indicate a protective role exerted by these NPs on the PSII, decreasing the uncontrolled dissipation of heat. This hypothesis is also supported by the $\mathrm{F}_{\mathrm{v}} / \mathrm{F}_{\mathrm{m}}$ ratio, which gives information on the maximum quantum efficiency of the PSII photochemistry. In $\mathrm{TiSiO}_{4}$ NPs exposed plants, this ratio remains around the $0.79-0.84$ values, which is an indicator of healthy plants (Maxwell \& Johnson 2000) and indicates a balance between reduction of plastoquinone $Q_{A}$ and its reoxidation by $Q_{B}$. This ratio is widely used as a sensitive endpoint for several stress-related photosynthetic disorders. For example, its disturbance was reported in some species exposed to $\mathrm{TiO}_{2} \mathrm{NPs}$ like T. aestivum (Dias et al. 2019). Also, in Chlorella pyrenoidosa, the inhibition of the photosynthetic activity was attributed to the damage of the reaction center of PSII (Middepogu et al. 2018).

Whilst the decrease of $F_{v} / F_{m}$ may indicate some slowly relaxing quenching processes and photodamage to PSII reaction centres, reducing the maximum quantum efficiency of PSII photochemistry (Baker \& Rosenqvist 2004), its increase - as observed in $\mathrm{TiSiO}_{4}$ NPs exposed plants - suggests increased protection to chlorophyll photoinhibition. This protective role is also in accordance with the increase of chlorophyll levels in $\mathrm{TiSiO}_{4}$ NPs exposed plants' leaves. Regarding light-adapted parameters, $\mathrm{F}_{\mathrm{v}}{ }_{\mathrm{v}} / \mathrm{F}_{\mathrm{m}}$, was positively correlated with the $100 \mathrm{mg} / \mathrm{L}$, meaning an increased capture efficiency of excitation energy by open PSII reaction centres in this NP concentration (Lima et al. 2002). Thus, we suggest that these NPs, directly or indirectly, stimulated the chlorophyll protection against photodamage (Wang et al. 2016), and/or increased chlorophyll synthesis to compensate for alleged increased damages as suggested by Middepogu et al. (2018). It should be 
stressed/highlighted that this protective role may have slightly increased the efficiency of the photophosphorylation process, which may lead to an increase in the amount of ATP and NADPH available to be used in Calvin Cycle.

Data related to the gas exchange parameters did not show any responsive effect with the studied $\mathrm{TiSiO}_{4} \mathrm{NPs}$ doses to L. sativa. However, the multivariance analysis showed that $\mathrm{g}_{\mathrm{s}}$ had a positive correlation with $50 \mathrm{mg} / \mathrm{L}$ and a Pn with opposite correlation for control plants and associated positively for 50 and $100 \mathrm{mg} / \mathrm{L}$ (Figure 5). A potential increase of $\mathrm{Pn}$ can be associated with the increase of $\mathrm{CO}_{2}$ supply from outside to the intercellular airspaces of leaves (Dias et al. 2019). However, the non-significant changes in Pn do not follow the increase of $\mathrm{Chl}$, nevertheless, the increase of $\mathrm{Chl}$ is not always accompanied by Pn increase (Da-yong et al. 2012). This is controlled by the stomatal function and the $\mathrm{CO}_{2}$ diffusion from intercellular airspaces towards the carboxylation sites. These NPs do not interfere with the accumulation of $\mathrm{CO}_{2}$ inside the mesophyll intercellular space, which suggests a proper function of $\mathrm{RuBisCO}$ and even a putative stimulation of its transcription, despite its relative amount not being changed. Different results with high concentrations of $\mathrm{TiO}_{2} \mathrm{NPs}_{\mathrm{s}}$ were reported, namely the $\mathrm{TiO}_{2} \mathrm{NPs}$ concentration of $1,000 \mathrm{mg} / \mathrm{L}$, which decreased $\mathrm{CO}_{2}$ fixation, transpiration rate, and stomatal conductance (Da Costa \& Sharma 2015). Also, we have recently demonstrated that $\mathrm{TiO}_{2} \mathrm{NPs}$ (anatase: rutile) are chronically applied to T. aestivum, decreased maximal and effective efficiency of PSII, net photosynthetic rate, transpiration rate, stomatal conductance, intercellular $\mathrm{CO}_{2}$ concentration, and starch content (Dias et al. 2019). On the other hand, the application of $\mathrm{SiO}_{2} \mathrm{NPs}_{\mathrm{s}}$ improves the gas exchange performance in Passiflora edulis with an increase of $\mathrm{Pn}, \mathrm{E}$, and gs (Costa et al. 2018). Overall, our data suggest that low doses of $\mathrm{TiSiO}_{4}$ NPs play some protective role in photosystem II, not having the negative impacts of $\mathrm{TiO}_{2} \mathrm{NPs}$.

The protective role of $\mathrm{TiSiO}_{4}$ NPs on the photosynthetic apparatus and the stimulation of RuBis$\mathrm{CO}$ subunits show stimulation of photosynthesis, supporting the observed plant growth increase. The TSS and starch levels are in line with all photosynthetic mechanisms under the effect of $\mathrm{TiSiO}_{4} \mathrm{NPs}$.
However, $\mathrm{TiO}_{2} \mathrm{NPs}$ had a different effect on glycometabolism, as it decreased the levels of starch in T. aestivum, putatively as a mechanism to maintain the soluble sugars levels (Dias et al. 2019). Also, changes in carbohydrates after exposure to $\mathrm{TiO}_{2} \mathrm{NPs}$ were reported in cucumber fruits (Servin et al. 2013). Contrarily, despite negative effects on chlorophyll, $\mathrm{TiO}_{2} \mathrm{NPs}$ increased total sugar and reduced sugar in basil exposed to $\mathrm{TiO}_{2} \mathrm{NPs}$ (Tan et al. 2018). Those authors suggested that $\mathrm{TiO}_{2} \mathrm{NPs}$ led to the transfer of an active electron which might disrupt enzyme activities related to glycometabolism, like those as $\beta$-amylases (Thalmann \& Santelia 2017), supporting the associated increase of sugar levels (Tan et al. 2018). Moreover, in $\mathrm{TiSiO}_{4}$ NPs exposed plants, while starch content showed some PCA-correlation with $\mathrm{Pn}$ and $\mathrm{RuBisCO}$ content, it showed an opposite correlation to these parameters in control plants, supporting a trend to increase with these NPs (Figure 5), however, this concentration did not show significant differences. Our results demonstrate that $\mathrm{TiSiO}_{4} \mathrm{NPs}$ doses up to $100 \mathrm{mg} / \mathrm{L}$ did not affect the plant glycometabolism, while the positive correlation of some parameters such as $\mathrm{Pn}$ and $\mathrm{RuBisCO}$ for $100 \mathrm{mg} / \mathrm{L}$ showed that maybe the endpoints were not detected, and other upper doses could have a positive effect for $L$. sativa.

Mainly, some differences between the reported effects of $\mathrm{TiO}_{2}$ and $\mathrm{TiSiO}_{4}$ NPs perhaps occurred by the presence of $\mathrm{Si}$ element. Once this mineral is related with plant recovery for abiotic stress (Etesami \& Jeong 2018) and is involved in photoprotection processes (Li et al. 2018), including the photosynthetic stimulation by the increase of the chlorophyll levels (Sarma et al. 2018), such as in L. sativa exposed to $\mathrm{TiSiO}_{4}$ NPs.

\section{CONCLUSIONS}

In conclusion, this is one of the first approaches regarding the bioactivity of the understudied $\mathrm{TiSiO}_{4}$ NPs, and it demonstrates that $\mathrm{TiSiO}_{4} \mathrm{NPs}_{\text {stimulate }}$ plant growth, and different doses may promote photosynthetic apparatus and performance in different ways, namely lower doses may stimulate chlorophyll levels, while higher doses show a stimulatory trend to stimulate photosynthetic performance. 
The tested doses did not have a negative effect on the net photosynthetic rate, nor influenced RuBis$\mathrm{CO}$ subunit amount. Being the first study on the biochemical effects of $\mathrm{TiSiO}_{4}$ NPs this study also shows the need to better understand how manufactures nanoparticles interfere in crop performance and identify safety and realistic doses.

Acknowledgements. Work supported by FEDER/COMPETE [POCI/01/0145/FEDER/007265 and FCT/MEC PT2020 UID/QUI/50006/2013]; FCT funded N. Mariz-Ponte, S. Sario, and R.J. Mendes, fellowships [SFRH/BD/138187/2018, SFRH/BD/138186/2018, SFRH/BD/133519/2017]; Also supported by National Funds by FCT - Portuguese Foundation for Science and Technology, under the project UID/AGR/04033/2019.

\section{Author contributions}

C. Santos planned the experiments. N. Mariz-Ponte, S. Sario and R.J. Mendes performed all experimental assays and statistical analysis. J. Moutinho-Pereira and C.M. Correia performed IRGA/ fluorimeter measurements. C. Correia supported N. Mariz-Ponte, S. Sario and R.J. Mendes in biochemical analyses. All authors contributed for statistical analysis, write and reviewed the manuscript.

\section{Declaration of no conflict of interests}

Authors state that they have no conflict of interests.

\section{REFERENCES}

AL MURAD, M. - KHAN, A.L. - MUNEER, S. 2020. Silicon in horticultural crops: Cross-talk, signalling, and tolerance mechanism under salinity stress. In Plants, vol. 9, no. 4, 460. DOI: $10.3390 /$ plants 9040460.

ALIABADI, T. - AFSHAR, A.S. - NEMATPOUR, F.S. 2016. The effects of nano $\mathrm{TiO}_{2}$ and Nano aluminium on the growth and some physiological parameters of the wheat (Triticum aestivum). In Iranian Journal of Plant Physiology, vol. 6, no. 2, pp. 1627-1635. DOI: 10.22034/ijpp.2016.539828.

ANDERSEN, C. - KING, G. - PLOCHER, M. - STORM, M. - POKHREL, L. - JOHNSON, M. - RYGIEWICZ, P. 2016. Germination and early plant development of ten plant species exposed to titanium dioxide and cerium oxide nanoparticles. In Environmental Toxicology and Chemistry, vol. 35, no. 9, pp. $2223-9$. DOI: $10.1002 /$ etc. 3374.

ASHKAVAND, P. - ZARAFSHAR, M. - TABARI, M. - MIRZAIE, J. - NIKPOUR, A. - BORDBAR, S.K. - STRUVE, D. - GABRIEL, S.G. 2018. Application of $\mathrm{SiO}_{2}$ nanoparticles as pretreatment alleviates the impact of drought on the physiological performance of Prunus mahaleb (rosaceae). In Boletin De La Sociedad Argentina De Botanica, vol.
53, no. 2, pp. 207-219. DOI: 10.31055/1851.2372.v53. n2.20578.

BAKER, N. - ROSENQVIST, E. 2004. Applications of chlorophyll fluorescence can improve crop production strategies: an examination of future possibilities. In Journal of Experimental Botany, vol. 55, no. 403, pp. 1607-1621. DOI: 10.1093/jxb/erh196.

BARAZZOUK, S. - BEKALÉ, L. - HOTCHANDANI, S. 2012. Enhanced photostability of chlorophyll- $a$ using gold nanoparticlesas an efficient photoprotector. In Journal of Material Chemistry, no. 22, pp. 25316-25324. DOI: 10.1039/C2JM33681B.

BASTOS, V. - DE OLIVEIRA, J.F. - BROWN, D. JONHSTON, H. - MALHEIRO, E. - DANIEL-DA-SILVA, A.L. - DUARTE, I.F. - SANTOS, C. - OLIVEIRA, H. 2016. The influence of Citrate or PEG coating on silver nanoparticle toxicity to a human keratinocyte cell line. In Toxicology Letters, vol. 249, pp. 29-41. DOI: 10.1016/j. toxlet.2016.03.005.

BEHBOUDI, F. - SARVESTANI, Z.T. - KASSAEE, M.Z. MODARES, S.A.M. 2018. Improving growth and yield of wheat under drought stress via application of $\mathrm{SiO}_{2}$ nanoparticles. In Journal of Agricultural Science and Technology, vol. 20, no. 7, pp. 1479-1492.

BUSSOTTI, F. - DESOTGIU, R. - CASCIO, C. - POLLASTRINI, M. - GRAVANO, E. - GEROSA, G. - MARZOULI, R. - NALI, C. - LORENZINI, G. - SALVATORI, E. - MANES, F. - SCHAUB, M. - STRASSER, R.J. 2011. Ozone stress in woody plants assessed with chlorophyll a fluorescence. A critical reassessment of existing data. In Environmental and Experimental Botany, vol. 73, pp. 19-30.

BOUGUERRA, S. - GAVINA, A. - KSIBI, M. - RASTEIRO, M.D.A.G. - ROCHA-SANTOS, T. - PEREIRA, R. 2016. Ecotoxicity of titanium silicon oxide $\left(\mathrm{TiSiO}_{4}\right)$ nanomaterial for terrestrial plants and soil invertebrate species. In Ecotoxicology and Environmental Safety, vol. 129, pp. 291-301. DOI: 10.1016/j.ecoenv.2016.03.038.

COSTA, B.N.S. - COSTA, I.D.J.S. - DIAS, G.D.M.G. - ASSIS, F.A.D. - PIO, L.A.S. - SOARES, J.D.R. - PASQUAL, M. 2018. Morpho-anatomical and physiological alterations of passion fruit fertilized with silicone. In Pesquisa Agropecuária Brasileira, vol. 53, no. 2, pp. 163-171. DOI: 10.1590/s0100-204x2018000200004.

COX, A. - VENKATACHALAM, P. - SAHI, S. - SHARMA, N. 2016. Silver and titanium dioxide nanoparticle toxicity in plants: A review of current research. In Plant Physiology and Biochemistry, vol. 107, pp. 147-163. DOI: $10.1016 / \mathrm{j}$. plaphy.2016.05.022.

CUI, H. - ZHANG, P. - GU, W. - JIANG, J. 2009. Application of anatasa $\mathrm{TiO}_{2}$ sol derived from peroxotitannic acid in crop diseases control and growth regulation. In NSTI-Nanotech, vol. 2 , pp. $286-289$.

DA COSTA, M.V.J. - SHARMA, P.K. 2015. Influence of Titanium dioxide nanoparticles on photosynthetic and biochemical processes in Oryza sativa. In International Journal of Recent Scientific Research, vol. 6, no. 1, pp. 2445-2451.

DA-YONG, L. - ZHI-AN, Z. - DIAN-JUN, Z. - LI-YAN, J. YUAN-LI, W. 2012. Comparison of net photosynthetic rate in leaves of soybean with different yield levels. In Journal of Northeast Agricultural University (English Edition), vol. 19, no. 3, pp. 14-19. DOI: 10.1016/S1006-8104(13)600173.

DIAS, M.C. - SANTOS, C. - PINTO, G. - SILVA, A.M.S. SILVA, S. 2019. Titanium dioxide nanoparticles impaired both photochemical and non-photochemical phases of photosynthesis in wheat. In Protoplasma, vol. 256, pp. 69-78. DOI: 10.1007/s00709-018-1281-6. 
DUHAN, J. - KUMAR, R. - KUMAR, N. - KAAUR, P. NEHRA, K. - DUHAN, S. 2017. Nanotechnology: The new perspective in precision agriculture. In Biotechnology Reports, vol. 15, pp. 11-23. DOI: 10.1016/j.btre.2017.03.002.

EL-RAMADY, H. - ABDALLA, N. - ALSHAAL, T. EL-HENAWY, A. - ELMAHROUK, M. - BAYOUMI, Y. - SHALABY, T. - AMER, M. - SHEHATA, S. - FÁRI, M. - DOMOKOS-SZABOLCSY, É. 2018. Plant nano-nutrition: perspectives and challenges. In GOTHANDAM, K.M. et al. (Eds.), Nanotechnology, Food Security and Water Treatment. Springer International Publishing AG, Cham. pp. 129-161. DOI: 10.1007/978-3-319-70166-0.

ETESAMI, H. - JEONG, B.R. 2018. Silicon (Si): Review and future prospects on the action mechanisms in alleviating biotic and abiotic stresses in plants. In Ecotoxicology and Environmental Safety, vol. 147, pp. 881-896. DOI: 10.1016/j. ecoenv.2017.09.063.

FRAZIER, T. - BURKLEW, C. - ZHANG, B. 2014. Titanium dioxide nanoparticles affect the growth and microRNA expression of tobacco (Nicotiana tabacum). In Functional \& Integrative Genomic, vol. 14, no. 1, pp. 75-83. DOI: 10.1007/s10142-013-0341-4.

GHOSH, M. - GHOSH, I. - GODDERIS, L. - HOET, P. - MUKHERJEE, A. 2019. Genotoxicity of engineered nanoparticles in higher plants. In Mutation Research/Genetic Toxicology and Environmental mutagenesis, vol. 842, pp. 132-145. DOI: 10.1016/j.mrgentox.2019.01.002.

GOHARI, G. - MOHAMMADI, A. - AKBARI, A. - PANAHIRAD, S. - DADPOUR, M.R. - FOTOPOULOS, V. KIMURA, S. 2020. Titanium dioxide nanoparticles $\left(\mathrm{TiO}_{2}\right.$ NPs) promote growth and ameliorate salinity stress effects on essential oil profile and biochemical attributes of Dracocephalum moldavica. In Scientific Reports, vol. 10, no. 1, pp. 1-14. DOI: 10.1038/s41598-020-57794-1.

GUERRIERO, G. - HAUSMAN, J.F. - LEGAY, S. 2016. Silicon and the plant extracellular matrix. In Frontiers in Plant Science, vol. 7, pp. 463. DOI: 10.3389/fpls.2016.00463.

GRACIA, L. - BELTRÁN, A. - ERRANDONEA, D. 2009 Characterization of the $\mathrm{TiSiO}_{4}$ structure and its pressure-induced phase transformations: Density functional theory study. In Physical Review B, vol. 80, no. 9, 094105. DOI: 10.1103/PhysRevB.80.094105.

IRIGOYEN, J.J. - EMERICH, D.W. - SÁNCHEZ-DÍAZ, M. 1992. Water stress induced changes in concentrations of proline and total soluble sugars in nodulated alfalfa (Medicago sativa) plants. In Physiologia Plantarum, vol. 84, no. 1, pp. 55-60. DOI: 10.1111/j.1399-3054.1992.tb08764.x.

JABERZADEH, A. - MOAVENI, P. - MOGHADAM, H.R.T. - ZAHEDI, H. 2013. Influence of bulk and nanoparticles titanium foliar application on some agronomic traits, seed gluten and starch contents of wheat subjected to water deficit stress. In Notulae Botanicae Horti Agrobotanici ClujNapoca, vol. 41, no. 1, pp. 201-207. DOI: org/10.15835/ nbha4119093.

JAMPÍLEK, J. - KRÁL'OVÁ K. 2017. Nanomaterials for delivery of nutrients and growth-promoting compounds to plants. In PRASAD, R. - KUMAR M. - KUMAR V. (Eds.), Nanotechnology. Springer, Singapore. DOI: 10.1007/978981-10-4573-8_9.

JI, Y. - ZHOU, Y. - MA, C. - FENG, Y. - HAO, Y. - RUI, Y. - WU, W. - GUI, X. - LE, V. - HAN, Y. - WANG, Y. - XING, B. - LIU, L. - CAO, W. - 2017. Jointed toxicity of $\mathrm{TiO}_{2}$ NPs and Cd to rice seedlings: NPs alleviated Cd toxicity and Cd promoted NPs uptake. In Plant Physiology and Biochemistry, vol. 110, pp. 82-93. DOI: 10.1016/j.plaphy.2016.05.010

KOVÁČIIK, P. - HAVRLENTOVÁ, M. - ŠIMANSKÝ, V.
2014. Growth and yield stimulation of winter oilseed rape (Brasssica napus L.) by Mg-Titanit fertiliser. In Agriculture (Pol'nohospodárstvo), vol. 60, no. 4, pp.132-141. DOI: 10.1515/agri-2015-0002.

KARUNAKARAN, G. - SURIYAPRABHA, R. - RAJENDRAN, V. - KANNAN, N. 2017. Influence of $\mathrm{ZrO}_{2}, \mathrm{SiO}_{2}$, $\mathrm{Al}_{2} \mathrm{O}_{3}$ and $\mathrm{TiO}_{2}$ nanoparticles on maize seed germination under different growth conditions. In IET Nanobiotechnology, vol. 10, no. 4, pp. 171-177. DOI: 10.1049/ietnbt.2015.0007.

KHEYRKHAH, M. - JANMOHAMMADI, M. - ABBASI, A. - SABAGHNIA, N. 2018. The effects of micronutrients (Fe And Zn) and beneficial nano-scaled elements (Si And Ti) on some morphophysiological characteristics of oilseed rape hybrids. In Agriculture (Pol'nohospodárstvo), vol. 64, no. 3, pp. 116-127. DOI: 10.2478/agri-2018-0012.

LEI, Z. - MINGYU, S. - CHAO, L. - LIANG, C. - HAO, H. - XIAO, W. - XIAOQING, L. - FAN, Y. - FENGQING, G. - FASHUI, H. 2007. Effects of Nanoanatase $\mathrm{TiO}_{2}$ on photosynthesis of spinach chloroplasts under different light illumination. In Biological Trace Element Research, vol. 119, no. 1, pp. 68-76. DOI: 10.1007/s12011-007-0047-3.

LI, D. - TIAN, M. - CAI, J. - JIANG, D. - CAO, W. - DAI, T. 2013. Effects of low nitrogen supply on relationships between photosynthesis and nitrogen status at different leaf position in wheat seedlings. In Plant Growth Regulation, vol. 70 , no. 3 , pp. 257-263. DOI: $10.1007 / \mathrm{s} 10725-013-$ 9797-4.

LI, Z. - SONG, Z. - YAN, Z. - HAO, Q. - SONG, A. - LIU, L. - YANG, X. - XIA, S. - LIANG, Y. 2018. Silicon enhancement of estimated plant biomass carbon accumulation under abiotic and biotic stresses. A meta-analysis. In Agronomy for Sustainable Development, vol. 38, no. 3, article 26. DOI: 10.1007/s13593-018-0496-4.

LIMA, A. - DAMATTA, F. - PINHEIRO, H. - TOTOLA, M. - LOUREIRO, M. 2002. Photochemical responses and oxidative stress in two clones of Coffea canephora under water deficit conditions. In Environmental and Experimental Botany, vol. 47, no. 3, pp. 239-247. DOI: 10.1016/S00988472(01)00130-7.

LIU, H. - LIU, Z.T. - REN, J. - LIU, Q.J. 2017. Structural, electronic, mechanical, dielectric and optical properties of TiSiO4: First-principles study. In Solid State Communication, vol. 251, pp. 43-49. DOI: 10.1016/j.ssc.2016.12.013.

LUYCKX, M. - HAUSMAN, J.F. - LUTTS, S. - GUERRIERO, G. 2017. Silicon and plants: current knowledge and technological perspectives. In Frontier in Plant Science, vol. 8, 411. DOI: 10.3389/fpls.2017.00411.

LYU, S. - WEI, X. - CHEN, J. - WANG, C. - WANG, X. PAN, D. 2017. Titanium as a beneficial element for crop production. In Frontier in Plant Science, vol. 8, 597. DOI: 10.3389/fpls.2017.00597.

MAITY, A. - NATARAJAN, N. - VIJAY, D. - SRINIVASAN, R. - PASTOR, M. - MALAVIYA, D.R. 2018. Influence of metal nanoparticles (NPs) on germination and yield of oat (Avena sativa) and berseem (Trifolium alexandrinum). In Proceedings of the National Academy of Sciences, India Section B: Biological Sciences, vol. 88, pp. 595-607. DOI: 10.1007/s40011-016-0796-x.

MAITY, A. - NATARAJAN, N. - PASTOR, M. - VIJAY, D - GUPTA, C.K. - WASNIK, V.K. 2018. Nanoparticles influence seed germination traits and seed pathogen infection rate in forage sorghum (Sorghum bicolour) and cowpea (Vigna unguiculata). In Indian Journal of Experimental Biology, vol. 56, pp. 363-372.

MAXWELL, K. - JOHNSON, G. 2000. Chlorophyll fluorescence - a practical guide. In Journal of Experimental 
Botany, vol. 51, no. 345, pp. 659-668. DOI: 10.1093/jexbot $/ 51.345 .659$

MEENA, R. - RUCHITA, P. - NARAYAN, S. - MADHU, R. - PAULRAJ, R. 2012. Comparative study of $\mathrm{TiO}_{2}$ and Ti$\mathrm{SiO}_{4}$ nanoparticles induced oxidative stress and apoptosis of HEK-293 cells. In Advanced Materials Letters, vol. 3, no. 6, pp. 459-465. DOI: 10.5185/amlett.2012.icnano.157.

MIDDEPOGU, A. - HOU, J. - GAO, X. - LIN, D. 2018. Effect and mechanism of $\mathrm{TiO}_{2}$ nanoparticles on the photosynthesis of Chlorella pyrenoidosa. In Ecotoxicology and Environmental safety, vol. 161, pp. 497-506.

OSAKI, M. - SHINANO, T. - TADANO, T. 1991. Redistribution of carbon and nitrogen-compounds from the shoot to the harvesting organs during maturation in field crops. In Soil Science and Plant Nutrition, vol. 37, no. 1, pp. 117-128. DOI: 10.1080/00380768.1991.10415017.

PARISI, C. - VIGANI, M. - RODRÍGUEZ-CEREZO, E. 2015 Agricultural nanotechnologies: What are the current possibilities? In Nanotoday, vol. 10, no. 2, pp. 124-127. DOI: 10.1016/j.nantod.2014.09.009.

PEREIRA, R. - ROCHA-SANTOS, T.A.P. - ANTUNES, F.E. - RASTEIRO, M.G. - RIBEIRO, R. - GONÇALVES, F. - SOARES, A.M.V.M. - LOPES, I. 2011. Screening evaluation of the ecotoxicity and genotoxicity of soils contaminated with organic and inorganic nanoparticles: the role of ageing. In Journal of Hazardous Material, vol. 194, pp. 345-354. DOI: 10.1016/j.jhazmat.2011.07.112.

QI, M. - LIU, Y. - LI, T. 2013. Nano-TiO improve the photosynthesis of tomato leaves under mild heat stress. In $\mathrm{Bi}$ ological Trace Element Research, vol. 156, no. 1-3, pp. 323-328. DOI: 10.1007/s12011-013-9833-2.

RODRIGUEZ, E. - SANTOS, C. - AZEVEDO, R. - CORREIA, C. - MOUTINHO-PEREIRA, J. - FERREIRA DE OLIVEIRA, J.M. - DIAS, M.C. 2015. Photosynthesis light-independent reactions are sensitive biomarkers to monitor lead phytotoxicity in a Pb-tolerant Pisum sativum cultivar. In Environmental Science and Pollution Research, vol. 22, no. 1, pp. 574-585. DOI: 10.1007/s11356-014$3375-9$.

RODRÍGUEZ-GONZÁLEZ, V. - TERASHIMA, C. - FUJISHIMA, A. 2019. Applications of photocatalytic titanium dioxide-based nanomaterials in sustainable agriculture. In Journal of Photochemistry and Photobiology C: Photochemistry Reviews, vol. 40, pp. 49-67. DOI: 10.1016/j. jphotochemrev.2019.06.001.

SANCHEZ-ZABALA， J. - GONZÁLEZ-MURUA， C. MARINO, D. 2015. Mild ammonium stress increases chlorophyll content in Arabidopsis thaliana. In Plant Signaling \& Behaviour, vol. 10, no. 3, e991596. DOI: 10.4161/15592324.2014.991596.

SARMA, R.S. - SHANKHDHAR, D. - SRIVASTAVA, P. SHANKHDHAR, S.C. 2018. Influence of silicon solubilizers on Silicon content, chlorophyll content $\left(\mathrm{mg} \mathrm{g}^{-1}\right)$ and photosynthetic efficiency in leaves at three different growth stages in rice genotypes. In Journal of Pharmacognosy and Phytochemistry, vol. 7, no. 2, pp. 2552-2558.

SERVIN, A.D. - MORALES, M.I. - CASTILLO-MICHEL, H. - HERNANDEZ-VIEZCAS, J.A. - MUNOZ, B. - ZHAO, L. - NUNEZ, J.E. - PERALTA-VIDEA, J.R. - GARDEA-TORRESDEY, J.L. 2013. Synchrotron verification of $\mathrm{TiO}_{2}$ accumulation in cucumber fruit: a possible pathway of $\mathrm{TiO}_{2}$ nanoparticle transfer from soil into the food chain. In Environmental Science \& Technology, vol. 47, no. 20, pp. 11592 - 11598. DOI: $10.1021 /$ es $403368 \mathrm{j}$.

SEKHON, B.S. 2014. Nanotechnology in agri-food production: an overview. In Nanotechnology, Science and Application, vol. 7, pp. 31-53. DOI: 10.2147/NSA.S39406.
SHABBIR, A. - KHAN, M.M.A - AHMAD, B. - SADIQ, Y. - JALEEL, H. - UDDIN, M. 2019. Efficacy of TiO, nanoparticles in enhancing the photosynthesis, essential oil and khusimol biosynthesis in Vetiveria zizanioides L. Nash. In Photosynthetica, vol. 57, no. 2, pp. 599-606. DOI: 10.32615/ps.2019.071.

SHATILOV, M.V. - RAZIN, A.F. - IVANOVA, M.I. 2019. Analysis of the world lettuce market. In IOP Conference Series: Earth and Environmental Science, vol. 395, no. 1, p. 012053. IOP Publishing. DOI: 10.1088/17551315/395/1/012053.

SIDDIQUI, M.H. - AL-WHAIBI, M.H. - FIROZ, M. AL-KHAISHANY, M. 2015. Role of nanoparticles in plants. In SIDDIQUI, M.H. et al. (Eds.), Nanotechnology and Plant Sciences, Chapter 2, pp. 19-35. DOI: 10.1007/978-3-319-14502-0 2.

SILVA, S. - OLIVEIRA, H. - CRAVEIRO, S.C. - CALADO, A.J. - SANTOS, C. 2016. Pure anatase and rutile + anatase nanoparticles differently affect wheat seedlings. In Chemosphere, vol. 151, pp. 68-75. DOI: 10.1016/j.chemosphere.2016.02.047.

SILVA, S. - CRAVEIRO, C. - OLIVEIRA, H. - SILVA, A.M.S. - SANTOS, C. 2017a. Wheat chronic exposure to $\mathrm{TiO}_{2}$-nanoparticles: Cyto- and genotoxic approach. In Plant Physiology and Biochemistry, vol. 121, pp. 89-98. DOI: 10.1016/j.plaphy.2017.10.013.

SILVA, S. - OLIVEIRA, H. - SILVA, A.M.S. - SANTOS, C. 2017b. The cytotoxic targets of anatase or rutile + anatase nanoparticles depend on the plant species. In Biologia Plantarum, vol. 61, no. 4, pp. 717-725. DOI: 10.1007/s10535017-0733-8.

SILVA, S. - DE OLIVEIRA, J.M.P.F. - DIAS, M.C. - SILVA, A.M. - SANTOS, C. 2019. Antioxidant mechanisms to counteract $\mathrm{TiO}_{2}$-nanoparticles toxicity in wheat leaves and roots are organ dependent. In Journal of Hazardous Materials, vol. 380, 120889. DOI: 10.1016/j.jhazmat.2019.120889.

SIMS, D.A. - GAMON, J.A. 2002. Relationships between leaf pigment content and spectral reflectance across a wide range of species, leaf structures and developmental stages. In Remote Sensing of Environment, vol. 81, no. 1-2, pp. 337-354. DOI: 10.1016/S0034-4257(02)00010-X.

SONI, N. - PRAKASH, S. 2012. Efficacy of fungus mediated silver and gold nanoparticles against Aedes aegypti larvae. In Parasitology Research, vol. 110, no. 1, pp. 175-184. DOI: $10.1007 / \mathrm{s} 00436-011-2467-4$.

SRIVASTAVA, V. - GUSAIN, D. - SHARMA, Y. 2015. Critical review on the toxicity of some widely used engineered nanoparticles. In Industrial \& Engineering Chemistry Research, vol. 54, no. 24, pp. 6209-6233. DOI: 10.1021/acs. iecr.5b01610.

TAHERI, R. - KOSASIH, B. - ZHU, H. - TIEU, A.K. 2018. Dual effects of $\mathrm{TiSiO}_{4}$ composite nanoparticles on dispersion stability and lubrication performance of vegetable oilin-water emulsions. In Lubrication Science, vol. 31, no. 1-2, DOI: $10.1002 / \mathrm{ls} .1443$.

TAN, W. - DU, W. - DARROUZET-NARDI, A.J. - HERNANDEZ-VIEZCAS, J.A. - YE, Y. - PERALTA-VIDEA, J.R. - GARDEA-TORRESDEY, J.L. 2018. Effects of the exposure of $\mathrm{TiO}_{2}$ nanoparticles on basil (Ocimum basilicum) for two generations. In Science of Total Environment, vol. 636, pp. $240-248$. DOI: 10.1016/j.scitotenv.2018.04.263.

THALMANN, M. - SANTELIA, D. 2017. Starch as a determinant of plant fitness under abiotic stress. In New Phytologist, vol. 214 , no. 3 , pp. $943-951$. DOI: $10.1111 /$ nph.14491.

TIGHE-NEIRA, R. - REYES-DÍAZ, M. - NUNES-NESI, A. RECIO, G. - CARMONA, E. - CORGNE, A. - RENGELJ, Z. - INOSTROZA-BLANCHETEAU, C. 2020. Titanium di- 
oxide nanoparticles provoke transient increase in photosynthetic performance and differential response in antioxidant system in Raphanus sativus L. In Scientia Horticulturae, vol. 269, 109418. DOI: 10.1016/j.scienta.2020.109418.

ZIDAR, P. - KOS, M. - ILIC, E. - MAROLT, G. - DROBNE, D. - JEMEC KOKALJ, A. 2019 Avoidance behaviour of isopods (Porcellio scaber) exposed to food or soil contaminated with Ag- and $\mathrm{CeO} 2$ - nanoparticles. In Applied Soil Ecology, vol. 141, pp. 69-78.

VARGHESE, J. - JOSEPH, T. - SEBASTIAN, M.T. 2011. Solgel derived $\mathrm{TiSiO}_{4}$ ceramics for high-k gate dielectric applications. In AIP Conference Proceedings, vol. 1372, no. 1, pp. 193 -197. DOI: 10.1063/1.3644442.

WANG, Y. - PENG, C. - FANG, H. - SUN, L. - ZHANG, H. FENG, J. - DUAN, D. - LIU, T. - SHI, J. 2015. Mitigation of $\mathrm{Cu}(\mathrm{II})$ phytotoxicity to rice (Oryza sativa $\mathrm{L}$ ) in the presence of $\mathrm{TiO}_{2}$ and $\mathrm{CeO}_{2}$ nanoparticles combined with humic acid. In Environmental Toxicology and Chemistry, vol. 34, no. 7 , pp. $1588-1596$. DOI: 10.1002/etc. 2953.

WANG, X.P. - YANG, X.Y. - CHEN, S.Y. - LI, Q.Q. - WANG, W. - HOU, C.J. - GAO, X. - WANG, L. - WANG, S.C. 2016. Zinc oxide nanoparticles affect biomass accumulation and photosynthesis in Arabidopsis. In Frontier in Plant Science, vol. 7, no. 6, 1243. DOI: 10.3389/fpls.2015.01243.
YANG, Z. - CHEN, J. - DOU, R. - GAO, X. - MAO, C. WANG, L. 2015. Assessment of the phytotoxicity of metal oxide nanoparticles on two crop plants, maize (Zea mays L.) and rice (Oryza sativa L.). In International Journal of Environmental Research and Public Health, vol. 12, no. 12, 15100-9. DOI: 10.3390/ijerph121214963.

YANG, F. - HONG, F.S. - YOU, W.J. - LIU, C. - GAO, F.Q. WU, C. - YANG, P. 2006. Influences of nano-anatase $\mathrm{TiO}_{2}$ on the nitrogen metabolism of growing spinach. In Biological Trace Element Research, vol. 110, no. 2, pp. 179-190. DOI: org/10.1385/BTER:110:2:179.

YAO, K.S. - WANG, D.Y. - HO, W.Y. - YAN, J.J. - TZENG, K.C. 2007. Photocatalytic bactericidal effect of $\mathrm{TiO}_{2}$ thin film on plant pathogens. In Surface and Coatings Technol$o g y$, vol. 201, no. 15 , pp. 6886-6888. DOI: 10.1016/j.surfcoat.2006.09.068.

ZAHRA, Z. - ARSHAD, M. - RAFIQUE, R. - MAHMOOD, A. - HABIB, A. - QAZI, I.A. - KHAN, S.A. 2015. Metallic nanoparticle $\left(\mathrm{TiO}_{2}\right.$ and $\left.\mathrm{Fe}_{3} \mathrm{O}_{4}\right)$ application modifies rhizosphere phosphorus availability and uptake by Lactuca sativa. In Journal of Agricultural and Food Chemistry, vol. 63, no. 31 , pp. $6876-6882$. DOI: $10.1021 /$ acs.jafc.5b01611.

Received: May 26, 2020 Accepted: December 14, 2020 